\title{
GESTÃo E PATOLOGIA CONTEMPORÂNEA
}

\section{Maria Lourdes Manzini-Covre}

Coordenadora do Núcleo de Subjetividade, Cultura e Cidadania, Universidade de São Paulo - São Paulo - SP, Brasil

lou.manzini@uol.com.br

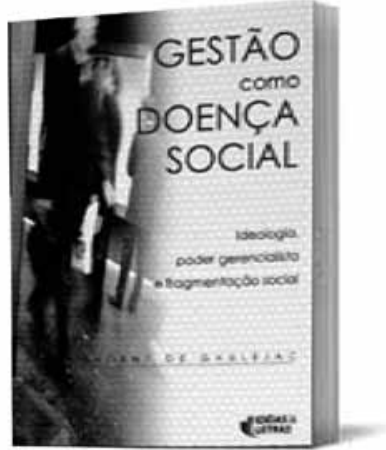

\section{GESTÃO COMO DOENÇA SOCIAL}

Vincent de Gaulejac. São Paulo: Ideias e Letras, 2007. 344 p.

As análises da transformação do self-made man em "assalariado" vêm sendo desenvolvidas desde o século XX. Entre os autores, cabe citar Wright Mills, autor de A Nova Classe Média (Zahar, 1969), que discute como empresários e gerentes especializados são substituídos por acionistas e novos capitalistas, e Harry Braverman (Trabalho e Capital Monopolista, LTC, 1987), cuja obra incide na análise do processo de degradação do trabalho desse gerente especializado e empresário individual.

Pode-se ter o livro aqui resenhado na seara desses debates, mas difere desses enfoques, inserido que está no contexto do século atual, de domínio extremo do capital financeiro, que acarretou mudanças radicais nas organizações e na vida contemporânea em geral. A primeira edição do livro La Societé Malade de la Gestion, escrito por Gaulejac, sociólogo e professor na Universidade de Paris 7 , foi publicado na França em 2005. O novo neste livro é sua abordagem socioclínica, sua apreensão do fenômeno social perpassada pela visão do fato social global (captada de Mauss), em que se insere a perspectiva subjetiva e institucional dos níveis socioeconômico e político-cultural.

O texto de Gaulejac desenvolve-se em duas grandes partes (com seus capítulos): a primeira intitula-se "Poder e Ideologias Gerencialistas", e a segunda, "Por que a gestão provoca doença?". O autor inicia a análise pela questão da gestão (e sua ideologia), transfigurada e distinta da relação capital-trabalho anterior, e que, agora, sob maior domínio capital financeiro, traz contradições mais profundas.

Refere-se à despersonalização das forças de poder (antes os proprietários), agora substituído por acionistas, multinacionais, managers que visam a maior remuneração possível do capital e de dividendos. Nesse processo, há uma liberdade do capital - tudo lhe é válido, desde que possibilite mais capital. Em decorrência desse processo, o âmbito do trabalho sofre grande regulação - baixos salários, horas irregulares, trabalho noturno, menos vantagens sociais - que, sem uma corporatividade trabalhista eficaz, não há uma resistência.

Na nova organização, os componentes submetem-se por manipulação inconsciente. A organização apresenta um contrato simbólico, sob uma ótica narcisística, que prende o gestor porque a organização promete compartilhar com esse indivíduo o seu sucesso. Vale dizer que Gaulejac provém de um grupo de liderança de Max Pagés, e dele se apreendem conceitos similares. No livro O Poder das Organizações (Atlas, 1990), Pagés estabelece a relação dos gestores com uma empresa-mãe de relação sedutora ambígua. Eles têm de internalizar as regras que irão compor uma estrutura "abstrata", o jogo. É este, com as suas regras, que dá impressão de liberdade e independência: cada um sente-se capaz de modificar o seu meio. Contudo, segundo Pagés, essa autonomia é controlada a distância e impessoalmente. Nesse jogo, o indivíduo vem a perceber a contradição entre liberdade e submissão. Cada responsável vê seu poder limitado pelo conjunto dos 
outros. Há um controle difuso, sem aparente poder sobre si. É que o poder se desloca e se despersonaliza. Com Gaulejac, diz-se do desenvolvimento na empresa de uma tecnologia política, supostamente não repressiva. A repressão é substituída pela sedução - a adesão ao projeto da empresa. Trata-se de canalizar ao máximo a energia libidinal dos gestores e transformá-la em força produtiva, não como empregados, mas como winners com gosto pelo sucesso, prontos a se devotar de corpo e alma ao projeto. Cada um é incitado a nele tomar iniciativas, agir livre e criativamente, ser autor no sentido das convicções da empresa, na qual a prioridade são os objetivos financeiros. Cada um deve provar sua competência, sua função, ao mesmo tempo que está submetido a prescrições. O gerencialismo celebra o enriquecimento, a liberdade e a autonomia, mas, simultaneamente, cria um estado de crise permanente. Nas relações sociais rígidas, cada um, em competição contínua com o(s) outro(s), luta para manter sua existência social naquele espaço. O sucesso (ou não) dos indivíduos depende dos acasos das carreiras profissionais e dos mercados financeiros. Reinam a racionalidade instrumental e um mundo sem sentido. Ressalta o autor que a crise contemporânea não é econômica, mas simbólica. Nesse sentido, pinça-se um exemplo na fala de um gerente - não sabemos a qual sentido nos consagrar.

Mas, em relação aos autores citados anteriormente, Gaulejac avança mais nas análises das contradições e consequências de relações rígidas. Salienta que, na gerência, a reflexão e a ação existem para servir à ininterrupta eficácia. A eficiência perde o seu sentido. A competição torna-se natural: acabar com o outro, com o colega, com a empresa concorrente. Perde-se a ética do trabalho. Business war, nomeia o autor. Na falta de sentido, é o próprio procedimento do gestor que se torna o possível provedor de sentido, diante de um sistema de medidas sofisticadas em total contradição com a intenção inicial, uma patologia na tradução do fenômeno social em linguagem matemática, sinaliza o autor. A organização do trabalho torna-se virtual. No universo gerencial, a subjetividade é mobilizada sobre objetivos, resultados, critérios de sucesso que tendem a excluir aquele gestor que não é útil, rentável. Vulnerável, o gestor culpa-se por não atender às exigências sempre maiores da organização. Está-se em um âmbito em que a pessoa tem de gerenciar a si mesma, ela é uma empresa. Gestores estão sempre ameaçados por demissões que são a expressão da brutalidade. Cada um é jogado fora, sem explicações, sem acompanhamento. Não pode contestar porque a ordem advém de um poder distante, inacessível. Nesse jogo, os gestores, diante da angústia, não podendo identificar as causas, não conseguindo elaborar seu sentido pela palavra, refugiam-se na hiperatividade, como modo de lutar contra o vazio do nonsense. Têm sempre que vencer. São condenados ao sucesso como ameaça objetiva - a de perder o lugar. A pressão leva ao cigarro, adição do trabalho, bebidas, psicoterápicos, cocaína etc.

Gaulejac fala de uma sociedade em desintegração caracterizada pelo operário perdido na desfiliação, explosão da burguesia, sem elo nas frações. Contudo, descobrem-se, na exposição de Gaulejac, certas saídas-mudanças, certo movimento: na própria explosão da burguesia e na divisão psíquica dos indivíduos. Que mudanças podem advir daí? Nas instituições? Nos indivíduos? Gaulejac atribui a possível resistência do gestor à sua divisão subjetiva.
Ante essa regulação, o gestor "coexiste" em si em dois comportamentos distintos - uma parte dele aceita a instrumentalização de si (necessita ser bem-visto, concorda com uma autoridade), mas preserva a parte de si que não concorda com isso. Acata a fachada em nome de ter de passar por isso para obter sucesso, mas segue sua libido, suas exigências narcísicas. Sente-se preservando certa autoestima, por não se deixar submeter totalmente. Mas o esforço para a adesão não preenche a necessidade de crer naquilo que faz. Tem de suportar a divisão, e também níveis de doença e as adições acima mencionadas.

De qualquer modo, diríamos que ainda se têm escolhas, jamais somos só heterônomos. Há, em todo indivíduo, o caráter concomitante de sujeitados e de sujeitos ativos pelo mesmo fato de que o âmbito do desejo é o do prazer e do impedimento, da liberdade e da submissão, como descrito por Manzini-Covre na obra No Caminho de Hermes e Sherazade (Vogal, 1986). Tem-se conhecimento, pelo contato com profissionais das clínicas psicanalíticas em São Paulo, de que existem vários gestores jovens já se tratando. E isso significa que, se esses alcançam sua unidade, tendem a ser pessoas que podem ter poder real sobre si e suas situações. Como exemplo, pode-se citar a pesquisa de Manzini-Covre publicada no livro Mudança de Sentido, Sujeito e Cidadania (Expressão e Arte, 2005) sobre a ação de uma paciente, subgerente de um banco, enfrentando muitas das situações acenadas ao longo desta resenha, que exercitava certa resistência (sendo um "polo organizador") e que alcançou certo sucesso para si e seus colegas.

Em suma, acredita-se que gestores e formandos em gestão podem usufruir muito da leitura do texto resenhado. 